\title{
Statyba
}

\section{CONTROL OF PROCESS OF BUILDING GEOMETRY DESIGN}

\section{L. Čiupaila \& R. Žiūrienè}

To cite this article: L. Čiupaila \& R. Žiūrienè (2001) CONTROL OF PROCESS OF BUILDING GEOMETRY DESIGN, Statyba, 7:3, 184-190, DOI: 10.1080/13921525.2001.10531722

To link to this article: https://doi.org/10.1080/13921525.2001.10531722

册 Published online: 30 Jul 2012.

Submit your article to this journal \lceil

山 Article views: 60 


\title{
PASTATU GEOMETRIJOS PROJEKTAVIMO PROCESO VALDYMAS
}

\author{
L. Čiupaila, R. Žiūrienẻ \\ Vilniaus Gedimino technikos universitetas
}

\section{Ivadas}

Tiriant pagrindinių šalies architektūrinio projektavimo firmų projektavimo techniką bei technologiją [1] nustatyta, kad kompiuteriai naudojami neįvertinant kompiuterinių technologijų galimybių. Visi projektuojami objektai nepriklausomai nuo jų paskirties apimties ir sudètingumo kuriami toje pačioje aplinkoje, naudojant tuos pačius įrankius. Universali, viskam tinkanti aplinka, yra griozdiška, nes vienu metu sukaupia per daug irankių, kurie konkrečiu atveju nereikalingi, trukdo dirbti. İrankių gausa sunkiai valdoma. Be to, dažniausiai neįvertinamas skaitmeninis informacijos perdavimo būdas, kuris suteikia nauju galimybių tiek informacijos analizès, tiek kokybiškai nauju projektavimo technologijų diegimo prasme.

Kol kas neivertinama, kad kompiuterio programa yra iš esmès naujo tipo ịankis [2] ir priemonè, kuri leidžia dešimteriopai padidinti žmogaus ne tik fizines, bet ir intelektualines galimybes. Viena iš kompiuterizavimo ypatybių yra ta, kad šis procesas nuolat kinta, tobuleja, todel eiliniam vartotojui jau nebereikia ir net neịmanoma pradèti nuo nulio. Tai, kas vieną kartą gerai padaryta (bazinès sistemos, atspindinčios ir realizuojančios dalyko esmę, o ne firmụ užmačias) tampa, gali ir turi tapti kitų darbų bei studiju pagrindu. Tiesa, kompiuteriniai metodai pasižymi ne vien tik didelèmis galimybèmis, bet ir valdymo sudètingumu, jiems ịsisavinti reikia laiko ir pastangu, taigi nauju technologiju ivaldymo problema dar vis laukia sprendimo ir, žinoma, nereikètų mažinti šiuolaikinių grafiniu sistemų studijoms skirto valandų skaičiaus, nes tuomet daugiau prarandama, negu sutaupoma (deja, taip daroma VGTU).

Statybos inžinerijoje apie $70 \%-90 \%$ informacijos pateikiama grafiniu būdu [3]. Pagal galiojančias nuostatas projekto grafikui suformuoti ir valdyti projekta- vimo stadijoje reikia daugiau kaip $70 \%$ laiko. Projekto skaičiuojamosios dalies atlikimas taip pat kito kompiuterinèse technologijose. Paradoksalu, kad daugiausia laiko užima paprasčiausi darbai (duomenu paruošimas ir ¡vedimas), o sudetingi skaičiavimai atliekami labai greitai. Turint šiuolaikini kompiuterį su modernia programine ịranga, situacija keičiasi iš esmès, pvz., brèžinius galima nubraižyti dešimteriopai sparčiau negu tradiciniais būdais. Ypač efektyvus darbas integruotai valdant duomenis, taip išvengiant rankinio duomenu paruošimo bei perdavimo, skaitmeninę informaciją apdorojant intelektinèmis priemonemis.

Šiuolaikinèmis kompiuterinèmis grafinèmis sistemomis galima automatiškai sudaryti brěžinius pagal erdvinius modelius ir atvirkščiai. Vizualaus trimačio modeliavimo galimybès yra milžiniškos, nors tam reikia nemažų vartotojo pastangu, tačiau realiame gyvenime, kol gamybos procese tiesiogiai dalyvauja žmogus, vienu atveju geriausia naudoti brèžinius, kitu - erdvinius modelius. Antra vertus, šiuo metu dar nèra erdvinio projektavimo tradiciju, kadangi kompiuteriniai metodai praktikoje tik pradedami taikyti ir metodiniai apibendrinimai praktiškai neskelbiami, nes tai kol kas yra komercijos dalykas. Nors erdvinių objektų naudojimas vizualizavimo procesą tarsi priartina prie tikrovès, kai iš elementų galima sumontuoti vaizdą arba modelị, darbas dvimačiame ekrane kelia daug problemų.

\section{Tyrimų tikslas}

Šiuolaikiniai statybos projektavimo metodai, kurie remiasi kompiuterinio projektavimo technologijomis, ne tik padeda projektuotojams, bet ir kelia daug ivairiu klausimų, jei tikimasi maksimaliai pasinaudoti kompiuteriu galimybèmis. Kai kurie projektavimo etapai (bréžiniu sudarymas, sąmatų skaičiavimai, mechanizmų bei 
medžiagu parinkimas ir kt.) jau senokai atliekami kompiuteriais. Naujausios programinès priemonès kompiuteriu leidžia atlikti ne tik atskirus darbus, bet ir kompiuterizuoti i̇vairių sričių specialistų žinias ir net patyrimą.

Pradiniu etapu tikslinga sukurti kompiuterinio projektavimo aplinkos modeli, skirtą pastatams projektuoti, kuriame:

- darbo įrankiai bei informacija būtł automatiškai sudaromi priklausomai nuo projektuojamo objekto tipo,

- būtų numatyta galimybè automatiškai kaupti patirti ir pasinaudoti turimu idirbiu,

- būtu ivertintas skaitmeninis informacijos automatizuoto valdymo būdas ir numatytos priemonès, kurios leistų maksimaliai pasinaudoti automatizuoto informacijos valdymo privalumais.

Straipsnyje aptariamos projektavimo problemos, $\mathrm{ku}-$ rias galima būtų realizuoti erdviniu modeliu, ir siūlomi būdai îvardytiems uždaviniams spręsti. Aptariami būdai automatizuotai duomenų analizei atlikti remiantis intelektinèmis priemonèmis.

\section{Pastatų erdvinio sprendimo vizualizavimo intelek- tinio modeliavimo aplinka}

Kompiuterinis darbas, kaip ir tradicinis, atliekamas pieštuku, neimanomas be irankių $[4,5]$. Tiesa, kompiuteriniai irankiai, jei jie neimituoja darbo pieštuku, gali būti galingesni, nes panaudoja intelektines galimybes. Patyrimas parode [4-6], kad darbui reikia keliu grupių komandu, tai:

- aplinkos ir procesu valdymas;

- grafinių uždaviniu sprendimo i̇rankiai;

- baziniy objektu (sienos, laiptai, langai, durys ir kt.) vizualizavimas;

- pagalbinès (grafinių ir tekstinių duomeny sąsajos, realistinio vaizdavimo, matomumo ir kt.) komandos.

\subsection{Intelektinès sistemos struktūra}

Per neilga kompiuterijos raidos laikotarpi programinè iranga darèsi vis galingesnè ir sudètingesnè. Šiuo metu naudojamu programinių sistemų aprašymai jau sveriami kilogramais ir paprastam vartotojui juos įsisavinti darosi vis kebliau. Programiniu bei techniniu priemoniu galimybès yra tokios didelès, kad jos gali ir privalo valdyti pačios save, tobulai tarnaudamos vartotojui.

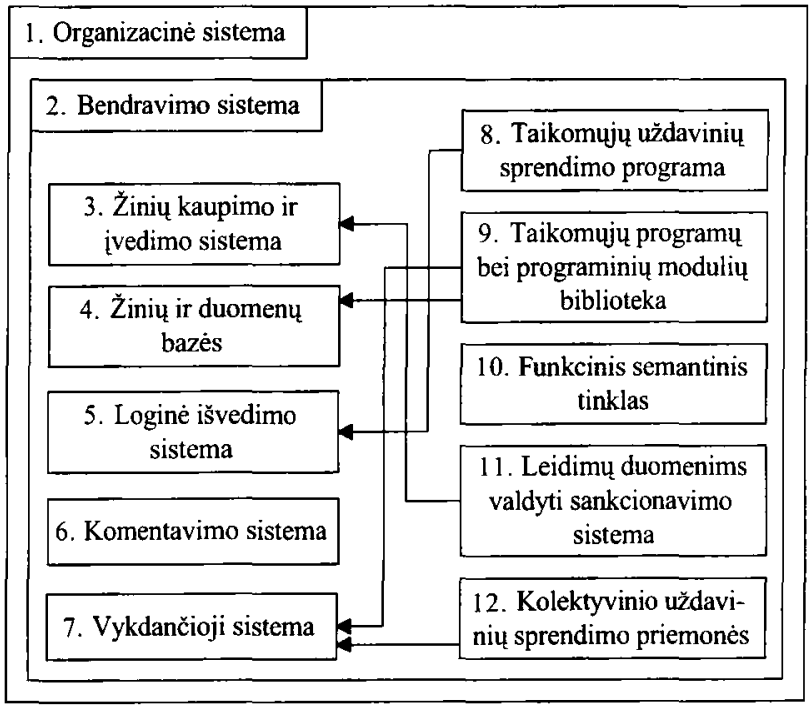

1 pav. Intelektinès sistemos apibendrinta schema

Fig 1. Scheme of intellectual system

Tai gali atlikti intelektinès sistemos [7], kurių apibendrinta schema pateikta 1 pav.

Darbe sprendžiami tik su geometriniu modeliavimu susiję intelektinès sistemos kTausimai ( 2 pav.), iš dalies atitinkantys sistemos $2-4,9$ modulius bei $4-9$

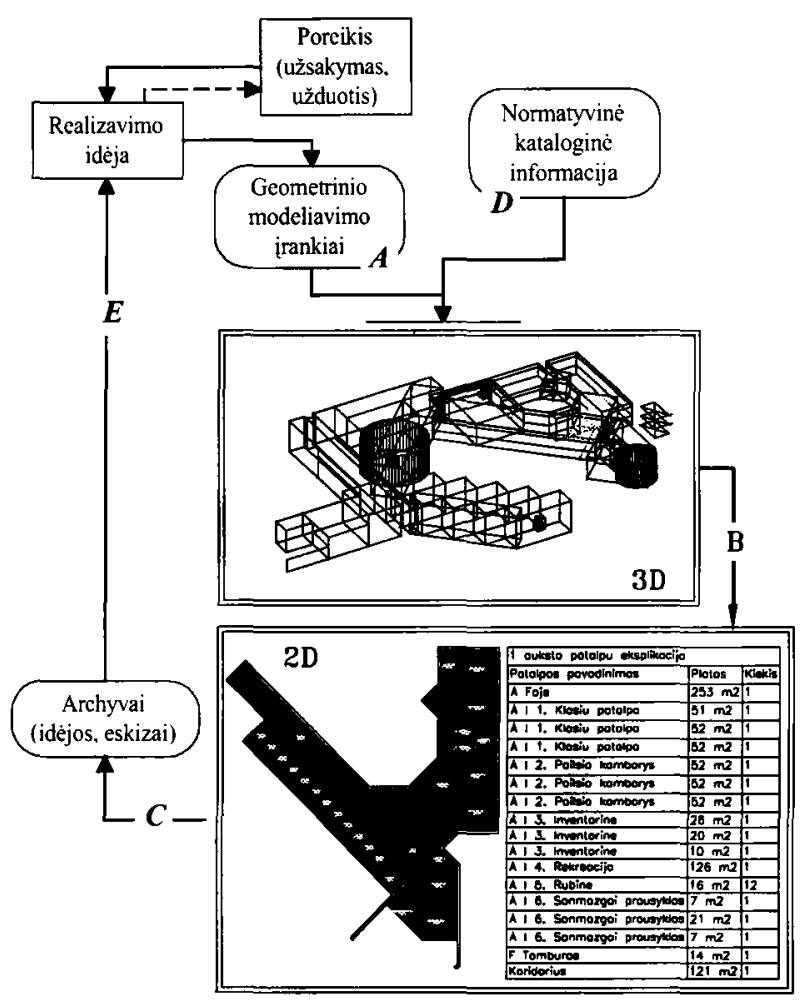

2 pav. Intelektinio modeliavimo schema

Fig 2. Scheme of intellectual modelling 
ryšius. Tai geometrinio modeliavimo (blokas A), normatyvinès bei kataloginès informacijos valdymo (blokas D), projektavimo dokumentų gavimo (procesas B), archyvu sudarymo ir panaudojimo valdymo (procesai $\mathrm{C}$ ir E) intelektiniai posistemiai.

\subsection{Darbo kompiuteriu problemos}

Nuo darbo pieštuku pereinant prie projektavimo kompiuteriu susiduriama su technologinemis ir kitokio pobūdžio problemomis. Kadangi kompiuteris yra kokybiškai nauja darbo priemonè, naudotis juo reikètų taikant atitinkamą technologija. Tačiau, deja, galingas kompiuteris dažniausiai naudojamas tik kaip elektroninis kulmanas.

Atlikus vietovès analizę, nagrinèjama projektavimo užduotis, braižomi pirminiai objekto eskizai. Dažniausiai jie piešiami popieriuje ranka, nes naudojant dabartines programas (AutoCAD, MicroStation ir kt. [8-10]) erdviniu kūnu valdymas yra sudètingas ir nelankstus, nors eskizų stadijoje tai turètú būti atliekama itin lengvai. Yra sistemu (Nemetschek D-Board [11]), kurios tarytum palengvina eskizavimo procesą - leidžia ,pieštuku" piešti ant ekrano, tačiau tokios sistemos iš esmès nieko neduoda, kadangi jomis negalima sukurti erdvinio modelio, kurị vèliau galima būtų konvertuoti i darbini trimati modelị.
Nupiešus pirminius eskizus, pradedama braižyti kompiuteryje. Dažniausiai dirbama pieštukine technologija, braižomi planai, pjüviai, fasadai, mazgai - visa tai tik 2D objekto projekcijos, kurios tarpusavyje nesusietos automatiniais ryšiais. Darbinis trimatis modelis nekuriamas, papildoma informacija (specifikacijos) irgi neturi automatinès sąsajos su braižomomis projekcijomis, todèl projektuojant su kiekvienu žingsniu korekcijos tampa vis labiau komplikuotos ir kartu dideja klaidų tikimybè.

Nesukürus erdvinio modelio, turinčio ryši su duomenu bazèmis, neimanomas automatizuotas daugelio operaciju, makrokomandu vykdymas (kiekybiniai, ekonominiai, stiprumo skaičiavimai).

Paprastai skirtingiems objektams - gyvenamajam namui, ligoninei ar garažui projektuoti naudojama ta pati darbo aplinka, tie patys irankiai, tie patys elementụ katalogai. Todèl susikaupia daug irankių, kurie perkrauna darbini lauką (3 pav.).

Irankiu gausa sunkiai valdoma. Naudojantis katalogais dažnai iškyla dilema - mažame kataloge surasti reikiamą elementą galima greičiau, tačiau ne visada galima rasti pageidaujamą elementa, o naudojantis dideliais katalogais, reikia patikrinti daug tuo metu galbūt nereikalingos informacijos. Didesnę dalị tokio darbo galima būtụ pavesti kompiuteriui.

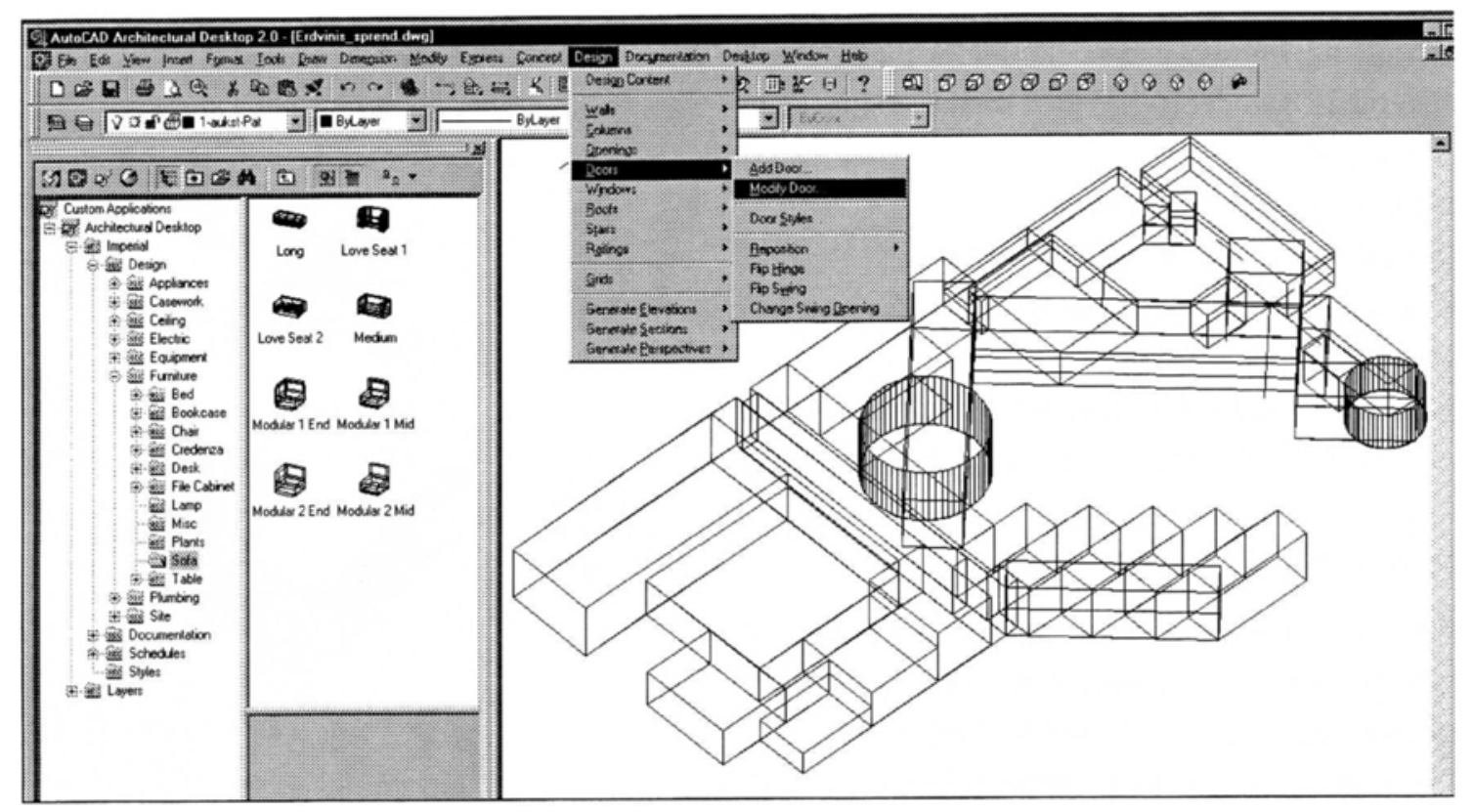

3 pav. Bazinès sistemos darbinis laukas

Fig 3. An interface of basic system 
Visų tipu objektai, neskaitant keliu išimčių, yra projektuojami jau ne pirmą kartą ir vis naujoms sąlygoms, tačiau daugeliu atveju iš esmès jie nedaug skiriasi nuo anksčiau sukurtų. Anksčiau sukurti analogiški objektai surandami ir panaudojami sprendžiant 2 pav. D uždavinị.

\subsection{Galimi valdymo sprendimo büdai}

Projektavimo procesui labai svarbu numatomo projektuoti objekto tipas. Dažniausiai jau yra žinoma statinio paskirtis, planuojamos išlaidos. Esminis skirtumas tarp dabar naudojamų ir siūlomos architekto darbo aplinkos - tai automatiškai susiformuojanti darbo aplinka. Projektavimo aplinka priklauso nuo pasirinkto projektuojamo objekto. Šie objektai yra sugrupuojami pagal tipologija (4 pav.). Tokios projektavimo eigos esmé ta, kad, išsirinkus projektuojamą objektą, automatiškai parenkama informacija ir irankiai, kurie bus reikalingi tik šio objekto projektavimui.

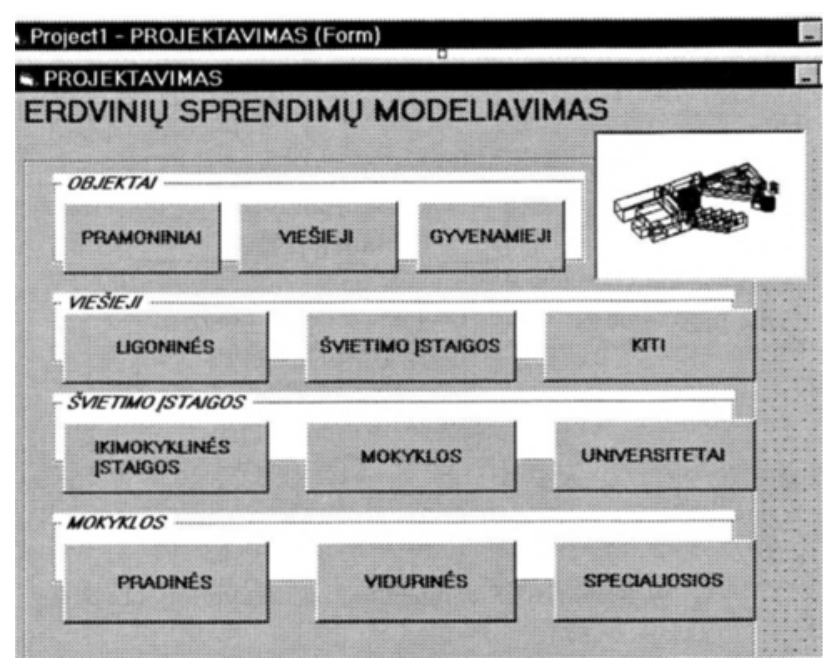

4 pav. Sistemos valdymas

Fig 4. System control

Pasirinkus objektą galimi du iš principo skirtingi projektavimo būdai: ieškoti tinkamiausio analogo ir ji redaguoti pagal naują situaciją arba kurti visiškai naują objektą.

Norint surasti tinkamiausią analogą, atliekama intelektinè analogo paieška ( 5 pav.).

Paieškos kriterijai gali būti ịvairūs: kaina, klimato sąlygos, paskirtis, kvadratūra, stilius, konstrukcinè schema ir pan. Analogų katalogai gali būti trejopi - skenuotieji pavyzdžiai (tiems analogams, kurie buvo nu-

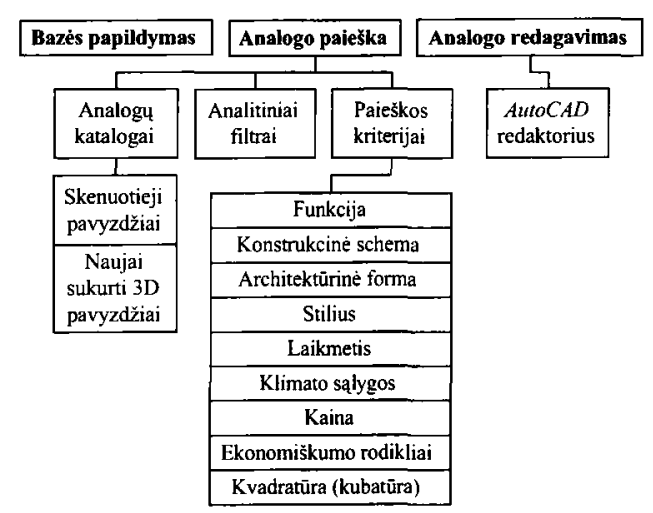

5 pav. Projektavimas pagal analoga

Fig 5. Design process based on analogue

braižyti popieriuje), 2D brèžiniai ir 3D brèžiniai. Išsirinktasis analogas gali būti panaudotas nepakeistas. Jeigu reikia ji keisti, jis koreguojamas ir naujasis variantas grąžinamas atgal i katalogus kaip naujas analogo pavyzdys.

Kuriant naują objektą kaip bazinę sistemą galima naudoti AutoCAD_Architectural Desktop R2 (toliau $A D T$ ) sistemą, nes ji valdo tūrini parametrini modelị ir todèl jos struktūroje yra prielaidų intelektiniam valdymui.

Kuriant koncepcini modeli ( 6 pav.), objekto kompozicija formuojama iš pagrindinių geometrinių kūnų (gretasienis, cilindras, sfera, prizmè, kūgis) atliekant sudeties, atimties, sankirtos veiksmus. Kuriamas parametrinis modelis, kurio redagavimas yra gerokai paprastesnis nei kietojo kūno (AutoCAD solid). Suformuotas modelis toliau naudojamas patalpoms planuoti, atitvaroms ir aukštams formuoti. Planuojant patalpas kiekvienam pasirinktam objektui iš anksto kuriama patalpu biblio-

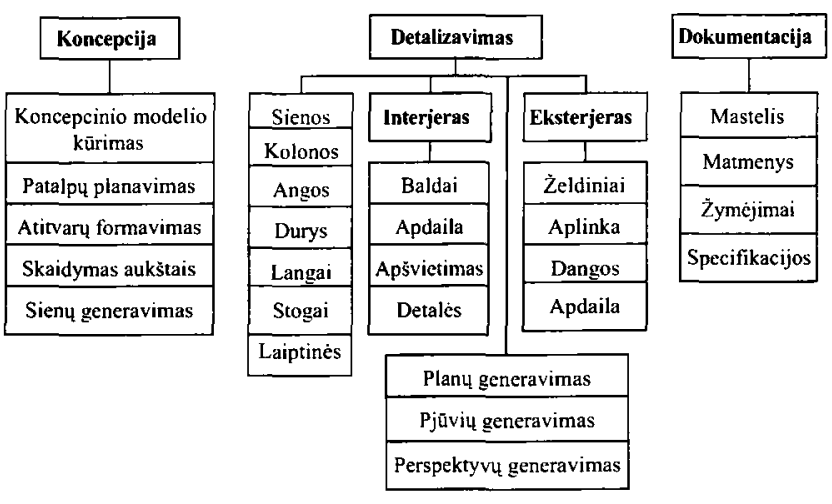

6 pav. Naujo objekto projektavimas

Fig 6. Design of an entirely new object 
teka, kurioje nurodomos visos reikalingos patalpos, ju ploto intervalai.

Detalizavimo stadijoje iš visų elementụ katalogu atrenkami tik reikalingi elementai konkrečiam objektui projektuoti.

\subsection{Tūrinio modelio intelektinio projektavimo} technologija, svarbiausios funkcijos ir schemos

Daug laiko ir jègu reikia suderinti projektą su juvairiomis tarnybomis, tokiomis kaip Priešgaisrinis departamentas, Higienos inspekcija, ivertinti, ar jis atitinka neigaliuju poreikius ir pan. Jis koreguojamas tol, kol ivykdomos sąlygos, nurodytos projektavimo užduotyje, normose bei standartuose. Daugumos sudetingụ koregavimų galima būtų išvengti, ivertinus projektams keliamus reikalavimus projektavimo metu.

Ši problema aktualiausia projektuojant griežtai reglamentuotus didelius viešuosius pastatus (mokyklas, ligonines ir pan.). Nèra paprasta suprojektuoti viešaji objektą taip, kad jis atitiktų visus reikalavimus. Tenka daugybę kartu tikrinti patalpu plotus, ju konfigūraciją plotu tarpusavio santyki.

\begin{tabular}{|ll|}
\hline Patalpos & Patalpu dydis \\
Angos & Baldu isdestymas \\
Laiptai & Apsvietimo kontrole \\
\hline Gaisrine sauga & Patalpu tarpusavio padetis \\
Aplinka visiems & Patalpu geografine padetis \\
\hline
\end{tabular}

\begin{tabular}{lll}
$\begin{array}{l}\text { Angos } \\
\text { Laiptai }\end{array}$ & $\begin{array}{l}\text { Isejimu is patalpos kiekis/dydis } \\
\text { Langu dydis }\end{array}$ \\
Gaisrine sauga & Duru/langu atidarymo kryptis \\
\hline
\end{tabular}

\begin{tabular}{lll} 
Konstrukcijos & Sienu silumine varza \\
\hline & Sienu garso izoliacija \\
\hline
\end{tabular}

7 pav. Kontrolès irankiai

Fig 7. Tools of control

Pasirinkus projektuojamą objektą (šiuo atveju mokyklą) detaliame meniu šalia kitų komandu pateikiamos funkcijos (7 pav.), galinčios pagal tam tikras sąlygas analizuoti reikiamus duomenis ir pateikti atsakymus. Sąlygos kuriamos remiantis normomis ir standartais kiekvienam objektui atskirai. Jos galètu būti îvairiausios, pvz., patikrinti, ar kiekvienos patalpos plotas $S$ neviršija nustatytu intervalų:

$$
S_{\text {Min }} \leq S \leq S_{\text {Max }},
$$

arba suskaičiuoti bendrą rekreacinès zonos plotą, skirtą pradiniu klasiu mokiniams $B R P S$, patikrinti, ar jis pakankamas numatomam mokinių skaičiui:

$$
B R P S \geq 0,05 \mathrm{~m}^{2} / 1 \text { mokiniui }
$$

ir ar šiu patalpų aukštis $R P H$ ne mažesnis už nustatytaji higienos normose $R P H_{n o r m}$ :

$$
R P H>R P H_{n o r m} \text {, }
$$

kur konkrečiu atveju $R P H_{n o r m}=3,25 \mathrm{~m}$.

Programa, patikrinus duomenis pagal vieną ar kitą sąlyga, priima sprendimą ir pateikia pasiūlymus arba grąžina juos atgal ị brèžini ( 8 pav.) ir išryškina koreguotinus elementus. Pasiūlymai priklausomai nuo užduoties gali būti ìvairūs, pvz., BRPS padidinti iki $108 \mathrm{~m}^{2}$. Pakoregavus pažymètų patalpų dydi, sąlygą galima tikrinti pakartotinai.

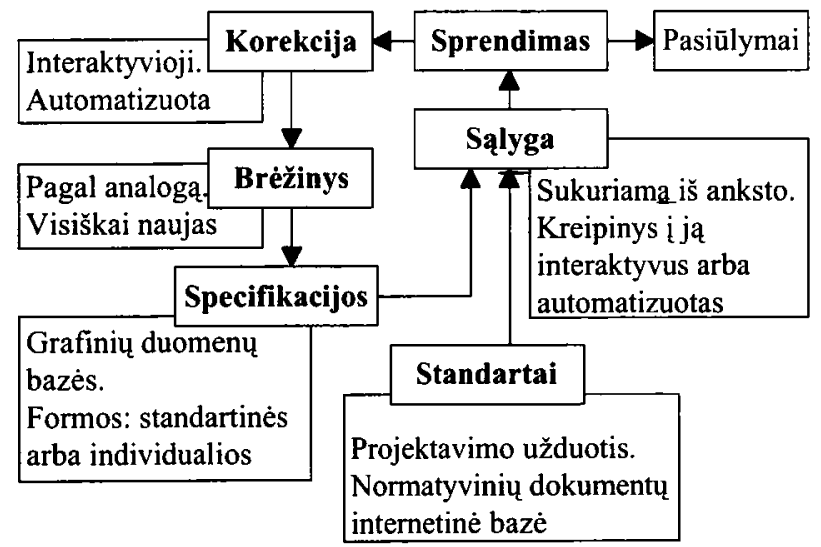

8 pav. Sąlygos tikrinimo ryšiu schema

Fig 8. Scheme of connections of condition checking

Kadangi $A D T$ operuoja parametriniu modeliu, galima sukurti funkcijas, kurios tikrintu ne tik ploty santykinę priklausomybę, bet ir kitus pastato bei jo daliu parametrus pvz., patalpos aukšti, langu angu plotă, tenkanti patalpos grindụ plotui, visus laiptu parametrus (pakopos aukšti ir plotị, maršo ilgi, ploti), evakuacinių išejjimu (koridoriu ir duru plotis) parametrus ir dar daugeli kitu. Žinant patalpu koordinates, galima patikrinti jų tarpusavio ryšius ir pastato funkcinę struktūrą. Programa, remdamasi ergonominiais reikalavimais, gali pasiūlyti optimalų baldụ išdèstymą patalpoje (mokykliniai suolai klasėse) ir apskaičiuoti, kiek ir kokių baldụ reikès visam objektui. 


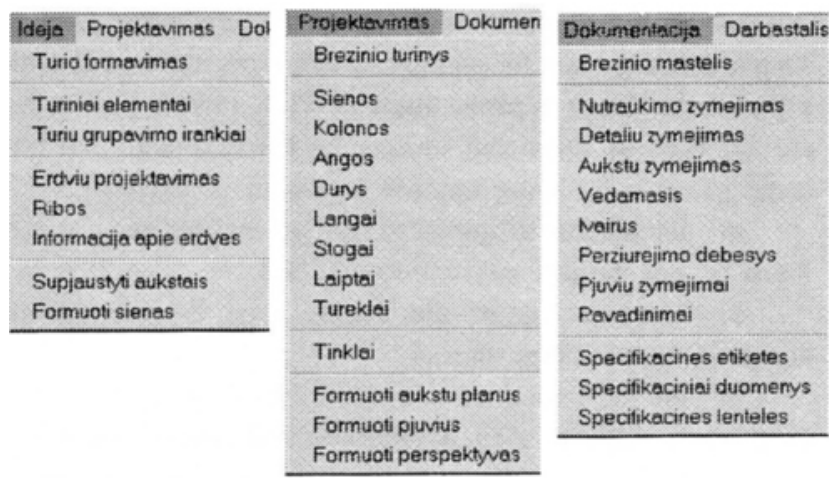

9 pav. Naujo objekto kūrimo irankiai

Fig 9. Tools for design of an entirely new object

Projektavimo pradinèje stadijoje architektas susipažịsta ir išnagrinèja statybos aikštelę arba esamą situaciją. Šiuo etapu jam reikès surinkti ir ivertinti daugybę informacijos. Šiam etapui pagreitinti ir informacijos tikslumui pagerinti siūlomi irankiai pateikti 9 pav. Pasirinkus objekto tipą ir išnagrinèjus vietovę kuriamas objekto koncepcinis modelis.

\section{Išvādos}

Išanalizavus šiuolaikines kompiuterinio projektavimo sistemas bei firmose taikomą projektavimo metodika, nustatyta, kad racionaliai pasinaudoti kompiuterinèmis galimybèmis galima tik suformulavus intelektinius kompiuterinio projektavimo modelius, leidžiančius iš principo naujai traktuoti projektavimą. Šiuolaikiniai kompiuteriai gali atlikti ne tik elementaru vizualizavima, bet ir automatizuotai pateikti bei valdyti ivairiausius duomenis, apimančius milžinišką medžiagu ivvairovę, galimus (jau realizuotus) architektūrinius sprendimus, jụ ekonomini ivertinima, egzistuojančius apribojimus (techniniai reikalavimai) ir automatizuotai kaupti bei ivertinti patyrimą.

Svarbiausios darbo išvados:

1. Atlikus Lietuvos architektūrinių firmų kompiuterinio projektavimo metodikos analizę nustatyta, kad kompiuteriai projektuojant naudojami kaip braižymo irankiai, atliekant operacijas tarsi pieštuku, kai vizualizuojamos atskiros linijos ar netgi taškai, o ne funkciniai objektai, kuriu realizavimas tapo galimas tik kompiuterinèmis priemonèmis. Kompiuterinio projektavimo integracija panaudojama ne daugiau kaip vienam projektui rudimentiniu lygiu.
2. Iš dažniausiai naudojamų kompiuterinių projektavimo sistemų analizès seka, kad naudojamos universalios ir specialiosios sistemos, kurios skiriasi savo galimybèmis bei komercine kaina. Nepaisant jau esamy techninių bei programiniu prielaidų, didžiausias laimèjimas yra integruotumo didinimas esant labai menkoms intelektinèms galimybèms.

3. Remiantis analize ir sudarytais intelektiniais modeliais parengta pastatu erdvinio sprendimo vizualizavimo aplinka:

a) aptartos svarbiausios erdvinio projektavimo aplinkos funkcijos ir sudaryti jų realizavimo algoritmai;

b) sudaryta irankių struktüros schema.

4. Naudojant pasiūlytus modelius ir algoritmus, sudaryti programiniai fragmentai, kurie buvo realizuoti sprendžiant pavyzdị. Ši medžiaga galètu būti naudinga mokomajame procese bei projektuojant. Sudaryti pagrindinių operaciju algoritmai ir programiniai moduliai, leidžiantys taikyti modernias projektavimo technologijas, taip pat panaudoti ir tradiciniu būdu sukurtus projektus.

\section{Literatūra}

1. R. Žiūrienè, L. Čiupaila. Automatizuoto projektavimo sistemu panaudojimo galimybès ir perspektyvos // Urbanistika ir architektūra, XXIII tomas, Nr. 3. Vilnius: Technika, 1999, p. 138-147.

2. А. Диозед. Компьютеры и образование: опыт Франции // Перспективы, 1988, № 4, с. 17-37.

3. Л. А. Чюпайла. К вопросу о компьютерном черчения // Tarptautinès asociacijos BALTGRAF konferencijos "Inžinerinè ir kompiuterinė grafika“" pranešimų medžiaga. Vilnius: Technika, 1998, p. 56-60.

4. L. Ciupaila. Grafiniai metodai projektavime // Statyba ir architektūra, Nr. 4, 1996, p. 29-30.

5. L. Čiupaila, J. Tamkienè. Pagrindinių gelžbetoniniu konstrukciju brèžiniu kompiuterinis modeliavimas // Konferencijos „Inžinerinè ir kompiuterinè braižyba“ pranešimu medžiaga. Kaunas: Technologija, 1997, p. 121- 124.

6. L. Čiupaila. TAIGRA-II taikomosios grafikos praktiniu uždavinių sprendimas ESM // Konferencijos „Inžinerinè ir kompiuterine braižyba" pranešimu medžiaga. Kaunas: Technologija, 1997, p. 116-121.

7. Г. С. Поспелов. Искусственный интеллект - основа новой информационной технологии. М.: Наука, 1988. $280 \mathrm{c}$.

8. ArchiCAD побеждает в Бостоне // Компьютер-пресс, апрель / 97, с. $254-255$.

9. А. Россоловский. 3D Studio VIZ. Впечатления от знакомства // Компьютер-пресс, август / 97, с. 276 278. 
10. С. Грачёв, Н. Султанов, А. Фохт-Бабушкин, А. Крылов. MicroStation TriForma - опыт практического использования в среде MicroStation 95 // САПР и графика, февраль / 98, с. 42-46.

11. Новая эра в рисовании. Программные решения фирмы Nemetschek // САПР и графика, апрель/ 2000, с. 5053.

Iteikta 20010205

\section{CONTROL OF PROCESS OF BUILDING GEOMETRY DESIGN}

\section{L. Čiupaila, R. Žiūriené}

\section{Sum mary}

Methods of the modern building design do not only help designers in their work, but also raise a number of different questions, especially in the cases of using maximum computer possibilities. One of the possible ways is to create a model of the interface of a workstation, which would have the following properties:

- The design process (design tools and information) has to be made automatically, depending on the type of the designed object.

- There should be a possibility to gain automatically one's experience and to use the existing information.

- The way of the automatic control of the digital information has to be evaluated, as well as the means of the maximum use of the automatic information control qualities should be estimated.

The controlling of the information becomes rational only by the use of intelligent systems (Fig 1). This investigation covers the problems related with a spatial modelling only (Fig 2). Basic systems could not be rational due to their general purpose (Fig 3), so it is necessary to create a structure of separate groups of problems (Fig 4). The course and the means of solving this problem depend on the way one chooses: the design according to the analogue (Fig 5) or the design of an entirely new object (Fig 6). The rational work could be possible only by making the means of modelling and control (Fig 7-9).

General conclusions:

1. While analysing the methods of computer design used in Lithuanian companies of architectural design, there has been determined: a) In the design process computers are being used as simple drawing tools for making different operations like with a pencil, to depict separate lines or even points. Computers are not used as functional objects, which realisation has become possible by using modern means of computer;

b) integration of computer design is used only in the limits of one project on rudimental level.

2. The analysis of the mostly used computer aided design (CAD) systems shows:

a) the most common and specialised CAD systems are used which differ in their possibilities and commercial price;

b) in spite of the existing technical and programme conditions, the highest achievement is only the development of integration with very low intelligent possibilities.

3. The interface of the visualisation of building spatial solution has been prepared on the base of analysis and created intellectual models:

a) the main functions of spatial design interface have been discussed, as well as algorithms of their realisation have been prepared;

b) a scheme of tool structure has been made.

4. By using the proposed models and algorithms there have been created the fragments of programme, which are realised by solving an example. This material could be used in the educational and practical design process. The algorithms of main operations and programmed models are made, enabling the use of modern design technologies and projects, created in traditional way.

Lionginas ČIUPAILA. Doctor, Associate Professor. Dept of Engineering Graphics. Vilnius Gediminas Technical University (VGTU, formerly VTU), Saulètekio al. 11, LT- 2040 Vilnius, Lithuania. E-mail: lac@fm.vtu.lt

Doctor (1984). First degree in Civil Engineering, Vilnius Civil Engineering Institute (1976, VISI, now VGTU). Research interests: engineering and computer graphics, artificial intelligence design systems in engineering.

Rytė ŽIŨRIENĖ. Doctoral student (since 1996). Dept of Engineering Graphics, Vilnius Gediminas Technical University (VGTU, formerly VTU), Sauletekio al. 11, LT-2040 Vilnius, Lithuania. E-mail: Ryte.Ziuriene@fm.vtu.lt

First degree in Architecture, Vilnius Civil Engineering Institute (1993, VISI, now VGTU). MSc (1996, VGTU). Research interests: architectural design, computer-aided design systems, computer graphics, intelligent design in engineering. 